\title{
Absence of myotonic dystrophy in southern African Negroids is associated with a significantly lower number of CTG trinucleotide repeats
}

\author{
Andrea Goldman, Michele Ramsay, Trefor Jenkins
}

\begin{abstract}
Myotonic dystrophy (DM) is associated with an increased number of CTG repeats in the $3^{\prime}$ untranslated region of the myotonin gene. Because DM has not been observed in southern African Negroids, a study of the CTG repeat polymorphism in this population was undertaken. A total of 210 unrelated subjects was studied by PCR analysis of the trinucleotide repeat in the $D M$ gene and the size and distribution of the CTG repeat were determined. The alleles ranged in length from five to 22 repeats. A previously undescribed $B g \Pi$ polymorphism was found which could lead to erroneous diagnosis of DM in people from this population. South African Negroids were found to have significantly fewer large repeat lengths than do white and Japanese populations. It is suggested that the occurrence of fewer large CTG repeats in the normal range may, in part, explain the absence of $D M$ in southern African Negroids.
\end{abstract}

(f Med Genet 1994;31:37-40)

Myotonic dystrophy (DM) is an autosomal dominant disorder that occurs with a prevalence of 1:8000 worldwide. The classical clinical features include myotonia, progressive muscle weakness and wasting, and many associated symptoms, including cataracts, intellectual impairment, and frontal balding. A hallmark of the disease is the extreme variation in severity and age of onset, both between and within families. ${ }^{1}$ Although the biochemical defect underlying this disorder is still unknown, the genetic defect has recently been shown to result from an unstable CTG repeat DNA sequence in the $3^{\prime}$ non-coding region of the myotonin protein kinase gene, located on chromosome $19 \mathrm{q} 13.3 .^{2-4}$ When amplified, this trinucleotide repeat is responsible for DNA instability and molecular pathology. In normal subjects, the CTG repeat is highly polymorphic, with the copy number ranging from five to $38 .^{5-7}$ In mildly affected myotonic dystrophy patients, the copy number is greater than 50 , and has been found to be as high as 2000 in severely affected patients. The expansion in size of the CTG repeat correlates well with disease severity and age of onset within families. $^{8}$
Although diagnosis of DM can be difficult owing to the wide range and severity of symptoms, the disorder has been described from many countries worldwide, including Japan, China, India, South Africa, Nigeria, and also in black American families. ${ }^{1910}$ No single case has, however, been reported in an indigenous Negroid or Khoisan person from southern Africa, ${ }^{9}$ despite a recent survey representing a population of more than 30 million. ${ }^{10}$ This survey, which also included other African countries, concluded that DM has a very low prevalence among ethnic Africans, especially in central and southern Africa.

Since DM has not been described in Negroids, a study was undertaken to verify the presence of the CTG repeat polymorphism in a Negroid population with minimal white admixture. The distribution of the CTG repeat in normal Negroid subjects was determined in an attempt to establish whether CTG repeat length correlated with the absence of DM in this population. It was hypothesised that smaller numbers of CTG repeats within the normal range would occur in the Negroid population and that these alleles may be more stable than larger alleles in the normal range.

\section{Subjects and methods}

A total of 210 unrelated southern African Bantu-speaking Negroids was studied. They were drawn from the various South African chiefdoms and were, in the main, male blood donors or staff of our Institute. Genomic DNA was extracted from peripheral blood using either a phenol-chloroform extraction ${ }^{11}$ or a simple salting out procedure. ${ }^{12}$ The polymerase chain reaction (PCR) with primers 101 and $102^{5}$ was used to amplify the region containing the CTG repeat. The PCR reaction was performed in a $25 \mu$ l reaction volume containing $100 \mathrm{ng}$ of genomic DNA, $10 \mathrm{mmol} / 1 \mathrm{Tris}-\mathrm{HCl}$, pH 8.8, $50 \mathrm{mmol} / 1 \mathrm{KCl}, 1.5 \mathrm{mmol} / 1 \mathrm{MgCl}_{2}$, $0.1 \%$ Triton-X, $200 \mu \mathrm{mol} / 1$ of dATP, dCTP and dGTP, $2.5 \mu \mathrm{mol}$ of dCTP, $50 \mathrm{ng}$ of each primer, $20-30 \mathrm{nCi}\left(\alpha-{ }^{32} \mathrm{P}\right) \mathrm{dCTP}$, and $2 \mathrm{U}$ Taq DNA polymerase. A total of 35 cycles of amplification $\left(94^{\circ} \mathrm{C}\right.$ for one minute, $66^{\circ} \mathrm{C}$ for one minute, $72^{\circ} \mathrm{C}$ for one minute) was carried out using a Perkin Elmer Cetus DNA Thermal Cycler. The denatured PCR products were run on $6 \%$ polyacrylamide gels. Samples with known CTG repeat numbers were run on every gel as controls and to facilitate the sizing of alleles. All samples found to have only one 


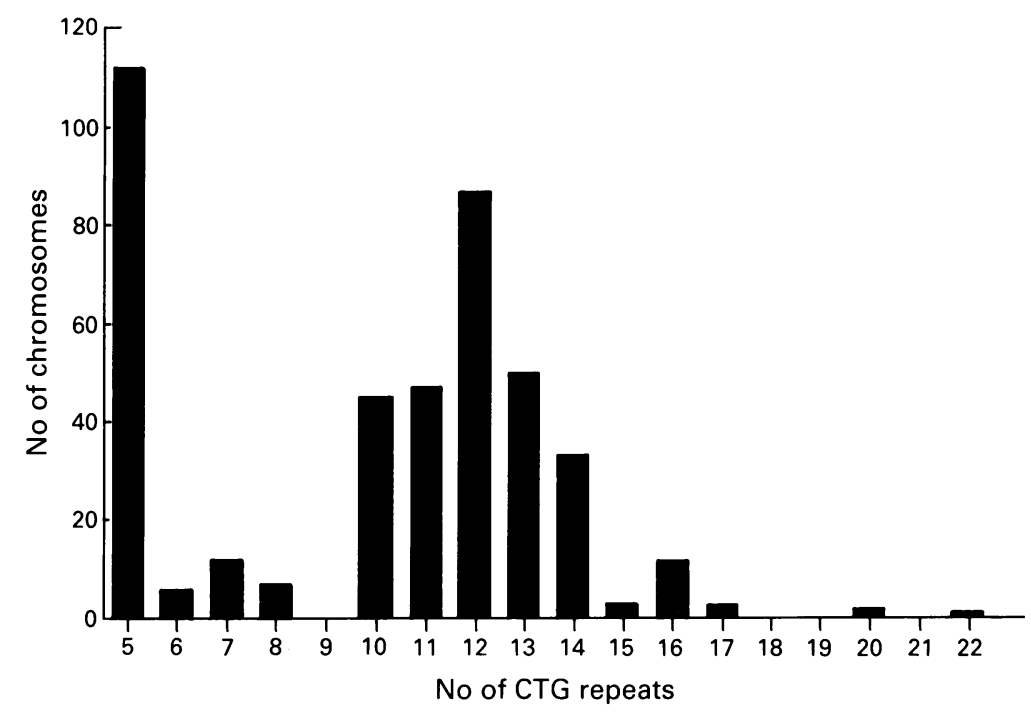

Figure 1 Distribution of alleles at the CTG repeat of the myotonin gene in the southern African Negroid population. A total of 420 chromosomes was examined.

allele were confirmed as homozygotes using Southern blotting. DNA was digested with $B g l \mathrm{I}$ or $B a m \mathrm{HI}$ and hybridised with $\mathrm{p} 5 \mathrm{~B} 1.4,{ }^{13}$ in order to detect larger alleles not amplifiable by PCR. Statistical significance was determined using the $\chi^{2}$ test with Yates's correction where necessary.

\section{Results}

The variability in CTG repeat length was analysed for 420 chromosomes and the findings are shown in fig 1 and table 1 . The genotypes of the subjects are not presented but are available to interested colleagues on request. A total of 14 alleles was found, ranging in size from five to 22 repeats. The most common allele had five repeats $(27 \%$ of chromosomes) and the majority of alleles were in the range of 10 to 14 repeats $(62 \%)$, with 12 repeats being most frequent $(21 \%)$ in this group. No chromosome was observed with nine repeats and very few alleles were found with more than 14 repeats $(5 \%)$. It is noteworthy that only three alleles were found to be longer than 19 repeats $(0 \cdot 7 \%)$. This system has a PIC value of 0.84 in the southern African Negroids.

Of the 210 subjects analysed using PCR alone, 36 appeared to be homozygous at the DM locus (16 subjects appeared to be $5 / 5$, nine $12 / 12$, six $13 / 13$, four $11 / 11$, and one $7 / 7$ ). Southern blot analysis of $B g l$ digested DNA

Table $1 \chi^{2}$ comparisons of southern African Negroid (N), European (E), and fapanese ( $(\mathcal{F})$ populations, with Yates's correction where necessary, for the common $C T G$ repeat alleles, 5-14, and the pooled others

\begin{tabular}{|c|c|c|c|c|c|}
\hline \multirow{2}{*}{$\begin{array}{l}\text { No of } C T G \\
\text { repeats }\end{array}$} & \multicolumn{2}{|c|}{ No of chromosomes } & \multicolumn{3}{|c|}{ p value } \\
\hline & Negroid & European* & Fapanese* & $N v E$ & $N v \mathfrak{f}$ \\
\hline 5 & 112 & 44 & 21 & $0 \cdot 113$ & $0 \cdot 147$ \\
\hline 10 & 45 & 3 & 1 & 0.003 & 0.001 \\
\hline 11 & 47 & 27 & 9 & 0.005 & $0 \cdot 420$ \\
\hline 12 & 87 & 18 & 25 & 0.082 & 0.519 \\
\hline 13 & 50 & 9 & 29 & $0 \cdot 109$ & $<0.001$ \\
\hline 14 & 33 & 9 & 1 & 0.726 & 0.009 \\
\hline Others & 46 & 20 & 20 & & \\
\hline Total & 420 & 130 & 106 & & \\
\hline
\end{tabular}

${ }^{*}$ Davies et al. ${ }^{14}$ probed with p5B1.4 confirmed homozygosity in 32 subjects, but showed a larger $(>3.4 \mathrm{~kb})$ fragment size in four. Further analysis was carried out using BamHI digested DNA probed with $\mathrm{p} 5 \mathrm{~B} 1.4$, a system reported to have greater resolution in detecting variation of the CTG repeat than the $B g l \mathrm{I}$ system. ${ }^{13}$ This failed to show the larger fragments seen with $B g l I$, suggesting that the larger sized $B g l \mathrm{I}$ fragments are the result of a polymorphism at a $B g l \mathrm{I}$ restriction enzyme recognition site, rather than being caused by a (CTG) $)_{n}$ expansion. This polymorphism has not been described previously.

The findings of this study were compared with those of Davies et al, ${ }^{14}$ who described the allele frequencies in non-DM subjects of European and Japanese populations (fig 2). Comparisons for each allele were done using the $\chi^{2}$ test (table 1). Significant differences were found for alleles 10 and 11 when comparing the southern African Negroids and the European populations and the differences were significant for alleles 10,13 , and 14 when comparing the southern African Negroid and Japanese populations. Also, the $\chi^{2}$ analysis of the overall distribution showed that the differences are highly significant (Negroid $v$ European, $\chi_{[14]}^{2}=56.0, \mathrm{p}<10^{-6}$; and Negroid $v$ Japanese, $\left.\chi_{[14]}^{2}=59 \cdot 0, \mathrm{p}<10^{-6}\right)$.

When alleles were divided into two groups, five to 14 repeats and greater than 14 repeats, Negroids appeared to have fewer alleles in the second group (0.05, SD 0.01) compared to Europeans $(0 \cdot 15$, SD $0 \cdot 03)$ and Japanese $(0 \cdot 19$, SD 0.04) (inset in fig 2). These differences are highly significant (Negroids $v$ European, $\chi^{2}{ }_{[1]}=13.6, p=0.0002$; Negroids $v$ Japanese, $\chi_{[1]}^{2}=22 \cdot 6, \mathrm{p}<10^{-5}$ ). If one were to analyse these data using the cut off point of Imbert et $a l^{15}$ (that is, the alleles were divided into two groups of five to 18 repeats and greater than 18 repeats), the differences between the three groups is even more significant (Negroids $v$ European, $\chi_{[1]}^{2}=33.4, \mathrm{p}<10^{-8}$; Negroids $v$ Japanese, $\left.\chi_{[1]}^{2}=19 \cdot 6, \mathrm{p}<10^{-5}\right)($ table 2$)$.

\section{Discussion}

The DM mutation involves the expansion of an unstable trinucleotide repeat (CTG) in the $3^{\prime}$ untranslated region of the myotonin gene. A similar mechanism of trinucleotide repeat expansion has been described in fragile $X$ mental retardation syndrome (CGG), ${ }^{1617}$ spinobulbar muscular atrophy (CAG), ${ }^{18}$ and, more recently, Huntington's disease $(\mathrm{CAG})^{19}$ and spinocerebellar ataxia type $\mathrm{I}^{20}$ Myotonic dystrophy has never been described in the southern African Negroid population, so a study on the CTG trinucleotide repeat in this population was undertaken in an attempt to explain its apparent absence. The CTG repeat polymorphism is present and 14 alleles of different repeat lengths were observed. Similar findings have been reported in other populations, where alleles 5,12 , and 13 are most common. ${ }^{51421}$

An unexpected but potentially important finding was the discovery of a BglI RFLP in 


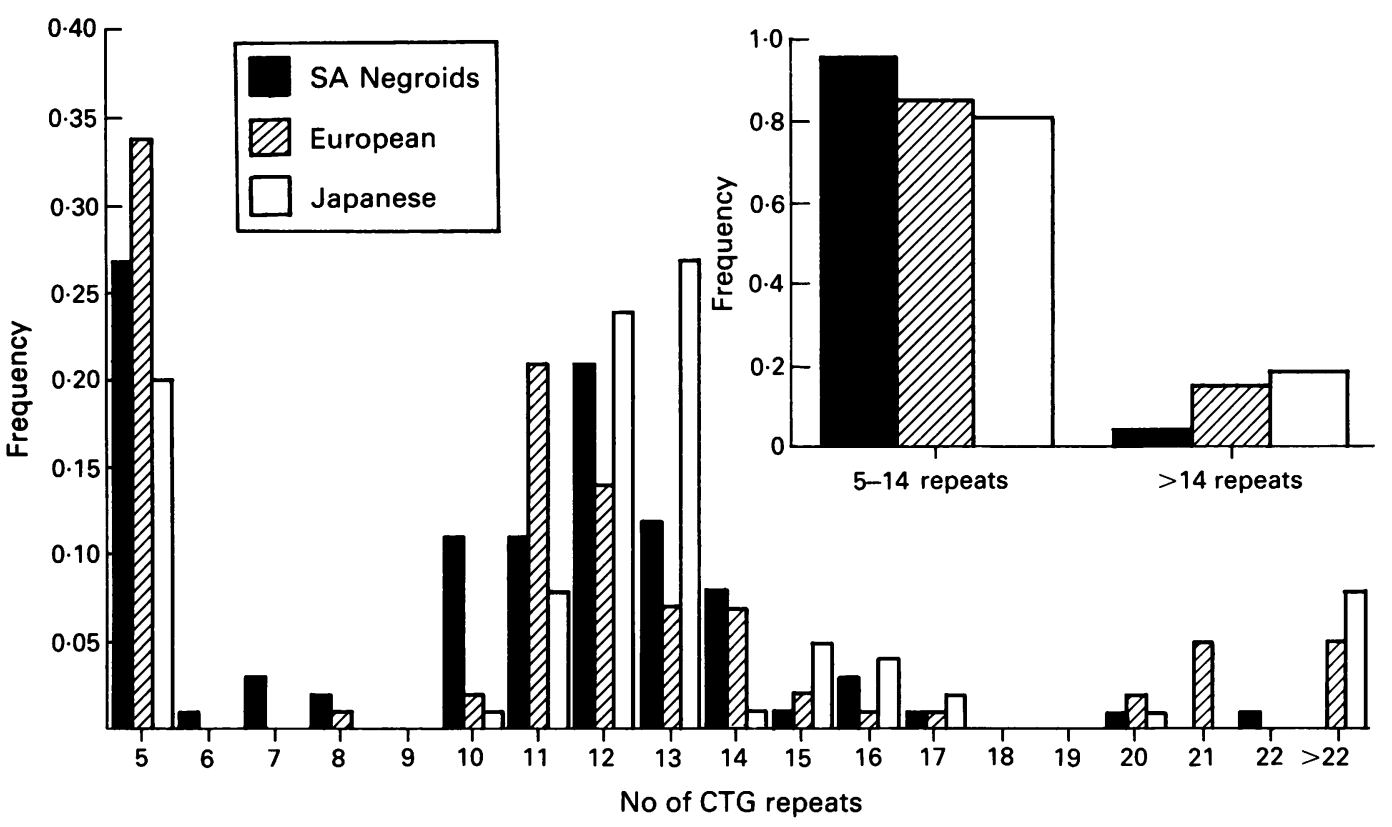

Figure 2 Frequency distribution of the CTG repeat in non-DM subjects in three populations: South African Negroid (present study), European, and fapanese. ${ }^{14}$ The inset (top right) shows the frequency comparison of two groups, one with alleles of 14 or fewer CTG repeats and the other with alleles with greater than 14 CTG repeat lengths.

the southern African Negroid population that has not been previously described. This RFLP may interfere with interpretation of results with the $B g l \mathrm{I} / \mathrm{p} 5 \mathrm{~B} 1.4$ system and could lead to erroneous diagnosis of $\mathrm{DM}$ in unaffected persons. It is possible, however, that this polymorphism may be confined to African peoples, that is, it is Negro specific.

The allele distribution in this southern African Negroid population, using either 14 or 19 repeats as the cut off point, was significantly different from the distribution in two previously described populations, namely Europeans and Japanese. ${ }^{14}$ In the South Africans, there is a paucity of larger repeats. In an attempt to explain the possible implications of this finding, it is instructive to compare and contrast DM with the other disorders caused by a similar mutation mechanism. There are two important considerations: (1) the effect of large repeat numbers on the stability of the triplet repeat, and (2) the evidence of founder chromosomes in the syndromes.

The molecular mechanisms that determine the stability of triplet repeats during meiosis are unclear at present. Triplet repeats mutate in a series of steps, with each increase in copy number increasing the further mutability of the repeat by some order of magnitude. ${ }^{22} \mathrm{~A}$ certain 'threshold' number of repeats is required before replication fidelity is com-

Table 2 Two comparisons of allele groups ( $A$ ) 5-14 and $>14$, and ( $B$ ) 5-18 and $>18$, between southern African Negroids $(N)$, European whites, $(E)$, and fapanese ( $\mathcal{F})$

\begin{tabular}{|c|c|c|c|c|c|}
\hline No of CTG repeats & $N$ & $E^{*}$ & $\boldsymbol{f}^{*}$ & $N v E$ & $N v \mathcal{F}$ \\
\hline \multirow{2}{*}{$\begin{array}{l}\text { Comparison A } \\
5-14 \\
>14 \\
\text { Comparison B } \\
5-18 \\
>18 \\
\text { Total }\end{array}$} & $\begin{array}{r}399 \\
21\end{array}$ & $\begin{array}{r}111 \\
19\end{array}$ & $\begin{array}{l}86 \\
20\end{array}$ & $\begin{array}{l}\chi^{2}{ }_{(1)}=13 \cdot 6 \\
\mathrm{p}<10^{-3}\end{array}$ & $\begin{array}{l}\chi_{[1]}^{2}=22 \cdot 6 \\
p<10^{-5}\end{array}$ \\
\hline & $\begin{array}{r}417 \\
3 \\
420\end{array}$ & $\begin{array}{r}115 \\
15 \\
130\end{array}$ & $\begin{array}{r}97 \\
9 \\
106\end{array}$ & $\begin{array}{l}\chi^{2}{ }_{p[1]}=33 \cdot 4 \\
\mathrm{p}<10^{-8}\end{array}$ & $\begin{array}{l}\chi_{[1]}^{2}=19 \cdot 6 \\
\mathrm{p}<10^{-5}\end{array}$ \\
\hline
\end{tabular}

* Davies et al. ${ }^{14}$ promised and the gene function/product is disrupted. Caskey et $a l^{1}$ suggested that the possible mechanism of triplet repeat expansion or instability may result from the difficulty of replication of GC rich sequences, thus causing inequality of DNA synthesis rate. This model predicts that longer alleles (maybe even those within the normal range) would be more prone to this mechanism, resulting in expansion.

Studies of fragile $\mathrm{X}$ families by Heitz et $a^{23}$ and Caskey $e t a l^{21}$ indicated that the size of the premutation is a major (and perhaps the only) determinant of the risk of transition from premutation to full mutation. There is thus a much greater risk of a large ( \pm 90 repeats) premutation being transformed to a full mutation. ${ }^{23}$ To extrapolate from these studies in fragile $\mathrm{X}$ families, it is possible that, at the DM locus, the larger copy number within the normal range may have a greater chance of progressing to the mutation range of repeats and hence the manifestation of DM in the next generation. The recent findings of Imbert et $a l^{15}$ also strongly suggest that the length of the CTG repeat in the DM gene is the main driving force for DM mutations. The authors proposed that the larger normal sized alleles with greater than 19 CTG repeats may have significant instability and thus may be the predisposing alleles for DM mutations.

Haplotype analysis of fragile $\mathrm{X}$ chromosomes showed that a few founder (ancestral) mutations are responsible for most fragile $\mathrm{X}$ cases. The 'high risk' haplotypes are widely distributed within the normal population and analysis of normal subjects with one of these haplotypes showed a high incidence of large CGG copy number at the upper end of the normal range. ${ }^{24}$ Similarly, investigations of linkage disequilibrium between Huntington's disease (HD) and DNA markers have suggested that at least a third of HD chromosomes are ancestrally related. ${ }^{1925}$ In two HD families, 
in which a new mutation was thought to have occurred, the most common haplotype seen on HD chromosomes was found with a CAG copy number in the upper end of the normal range. ${ }^{19}$ The clinical appearance of HD in these two cases was associated with expansion of the CAG repeat. These findings suggest that there may be a pool of subjects with repeat numbers in the upper but normal range whose descendants are at an increased risk of subsequent mutation owing to the relationship between copy number and mutability. ${ }^{26}$

We hypothesised that South African Negroids, a population in which DM has not, to our knowledge, been described, would have a lower frequency of the large CTG repeat alleles in the normal range than do populations in which the disease occurs at relatively high prevalence. This has been confirmed. The molecular mechanisms that determine the stability of DM alleles during inheritance are unclear at present. The findings in fragile $\mathrm{X}$, the two HD families, and, more recently, the study of the DM locus in 149 subjects ${ }^{15}$ may suggest that, at the DM locus, the larger CTG copy number (alleles) within the normal range may be particularly susceptible to expansion into the mutation range. This may explain the absence of DM in South African Negroids. Expansion of the repeat lengths to 19 or more CTG repeats is in complete linkage disequilibrium with allele 1 (insertion) in the insertion/ deletion polymorphism, thus suggesting the existence of a primordial predisposing mutation. ${ }^{21027}$ The CTG repeat lengths of 19 or more have been shown to be very rare in South African Negroids and it will be of interest to determine the frequencies of, and association with, the alleles (1 and 2 ) of the insertion/ deletion polymorphism, as well as the frequencies and associations of other closely linked polymorphic markers.

We thank Keith Johnson for the gift of the probe p5B1.4

1 Harper PS. Myotonic dystrophy. 2nd ed. London: Saunders,

2 Harley HG, Brook JD, Rundle SA. Expansion of an unstable DNA region and phenotypic variation in myotonic

dystrophy. Nature 1992;355:545-6.
3 Buxton J, Shelbourne P, Davies J. Detection of an unstable fragment of DNA specific to individuals with myotonic dystrophy. Nature 1992;355:547-8.

4 Aslanidis C, Jensen G, Amemiya C, et al. Cloning of the essential myotonic dystrophy region and mapping of the putative defect. Nature 1992;355:548-51.
puts

5 Brook JD, McCurrach ME, Harley HG, et al. Molecular basis of myotonic dystrophy: expansion of a trinucleotide (CTG) protein family member. Cell 1992;68:799-808.
pating a

6 Fu YH, Pizzuti A, Fenwick RJ Jr, et al. An unstable triplet repeat in a gene related to myotonic muscular dystrophy. Science 1992;255:1256-8.

7 Mahadevan M, Tsilfidis C, Sabourin L, et al. Myotonic dystrophy mutation: an unstable CTG repeat in the $3^{\prime}$ dystrophy mutation: an unstable CTG repeat in the $3^{\prime}$
untranslated region of the gene. Science 1992;255:1253-5.

8 untranslated region of the gene. Science 1992;255:1253-5. onset with CTG trinucleotide repeat amplification in onset with CTG trinucleotide repeat amplification
myotonic dystrophy. $\mathcal{F}$ Med Genet 1992;29:774-9.

9 Lotz BP, Van Den Meyden CH. Myotonic dystrophy. Part I. A genealogical study in the northern Transvaal. $S$ Afr Med $\mathcal{F} 1985 ; 67: 812-4$.

10 Ashizawa T, Epstein HF. Ethnic distribution of myotonic dystrophy gene. Lancet 1991;338:642-3.

11 Miller SA, Dyk DD, Pelesky HF. A simple salting-out procedure for extracting DNA from human nucleated cells. Nucleic Acids Res 1988;16:3.

12 Sykes BG. DNA in heritable disease. Lancet 1983;ii:787-8.

3 Shelbourne P, Winqvist R, Kunert E, et al. Unstable DNA may be responsible for the incomplete penetrance of the myotonic dystrophy phenotype. Hum Mol Genet 1992;1:467-73.

14 Davies JD, Yamagata H, Shelbourne P, et al. Comparison of the myotonic dystrophy associated CTG repeat in European and Japanese populations. $\mathcal{f}$ Med Genet 1992;29:766-9.

15 Imbert G, Kretz C, Johnson K, Mandel JL. Origin of the expansion mutation in myotonic dystrophy. Nature Genet 1993;4:72-6.

16 Yu S, Prichard M, Kremer E, et al. Fragile X genotype characterized by an unstable region of DNA. Science 1991;252:1179-81.

17 Kremer EJ, Prichard M, Lynch M, et al. Mapping of DNA instability at the fragile $X$ to a trinucleotide repeat seinstability at the fragile $X$ to a trinucleotide
quence $p(C G G) n$. Science $1991 ; 252: 1711-4$.

$18 \mathrm{La}$ Spada A, Wilson EM, Lubahn DB, et al. Androgen receptor gene mutations in $\mathrm{X}$ linked spinal and bulbar muscular atrophy. Nature 1991;352:77-9.

19 HD Consortium. A novel gene containing a trinucleotide repeat that is expanded and unstable on Huntington's disease chromosomes. Cell 1993;72:971-83.

20 Orr HT, Chung M, Banfi S, et al. Expansion of an unstable trinucleotide repeat in spinocerebellar ataxia type $I$. Nature Genet 1993;4:221-6.

21 Caskey CT, Pizzuti A, Fu YH, et al. Triplet repeat mutations in human disease. Science 1992;256:784-8.

22 Suthers GK, Huson SM, Davies KE. Instability versus predictability: the molecular diagnosis of myotonic dystrophy. $\mathcal{F}$ Med Genet 1992;29:761-5.

23 Heitz D, Devys D, Imbert G, et al. Inheritance of the fragile $\mathrm{X}$ syndrome: size of the premutation is a major determinant of the transition to full mutation. $f$ Med Genet 1992;29:794-801.

24 Richards RI, Holman K, Friend K, et al. Evidence of founder chromosomes in fragile $\mathrm{X}$ syndrome. Nature Genet 1992;1:257-60.

25 MacDonald ME, Novellette A, Lin C, et al. The Huntington's disease candidate region exhibits many different haplotypes. Nature Genet 1992;1:93-103.

26 Richards RI, Sutherland GR Dynamic mutations: a new class of mutations causing human disease. Cell class of mutation

27 Harley HG, Walsh KV, Rundle S, et al. Localisation of the myotonic dystrophy locus to $19 \mathrm{q} 13.2-19 \mathrm{q} 13.3$ and its relationship to twelve polymorphic loci on $19 \mathrm{q}$. Hum Genet 1991;87:73-80. 